\title{
Educação e espiritualidade: limites e possibilidades de um encontro pedagógico no Ensino Religioso
}

\author{
Education and spirituality: limits and possibilities of a meeting \\ in a pedagogical Religious Education
}

\begin{abstract}
Célia Smarjassi
Doutoranda em Ciências da Religião pela PUC-SP, Mestre em Psicologia da Educação pela Pontifícia Universidade Católica de São Paulo (PUC-SP), São Paulo, SP - Brasil, e-mail: celia_smarjassi@yahoo.com.br; celsmarjassi@hotmail.com
\end{abstract}

\section{Resumo}

0 artigo busca descortinar uma realidade que se relaciona com os avanços da nova biologia, da genética, da neurociência, da teologia, da filosofia e da psicologia, na busca de Deus e da experiência religiosa. Os novos conceitos dessas ciências, embora com limites, abrem possibilidades para se repensar o Ensino Religioso (ER) como um fecundo terreno para se recuperar, e desenvolver, de forma plural e universal, o fenômeno espiritualidade por configurar a essência universal das religiões, sua mola propulsora tão peculiar no Homo Sapiens. Para a efetivação deste trabalho convocamos alguns autores, segundo a necessidade, para elaborar um projeto de ER que vise à aprendizagem significativa.

Palavras-chave: Ensino religioso. Espiritualidade. Aprendizagem significativa. 


\section{Abstract}

This article seeks to uncover a reality that relates new advances in Biology, Genetics, Neuroscience, Theology, Philosophy and Psychology to the search of God and religious experiences. The new concepts of science, albeit their limitations, make it possible to rethink Religious Education Classes (RE) as a fertile ground to recover and develop the phenomenon of spirituality as a plural and universal one. It also helps one understanding the universal essence of religion as a driving force peculiar to Homo Sapiens. In order to carry this work on, some authors were call upon as needed, allowing us to develop a project that aims at RE significant learning.

Keywords: Religious education. Spirituality. Meaningful learning.

\section{0 desvelar das inquietações temáticas}

Desde a idade paleolítica, o homo religiosus está em pé, com os braços levantados [...]. Nas montanhas da Valcamonica, vemos esse homem, representado por centenas de exemplares, alçar o olhar, os braços e as mãos. Perscrutando o céu, busca no alto uma 'realidade absoluta', 'um ser supremo', invisível, mas real, simbolizado pela luz do sol. Essa procura está por toda parte, no tempo e no espaço, atravessa a humanidade (MONDIN, 1997, p. 49).

O planeta Terra com seus 510 milhões de quilômetros quadrados e seus quase 7 bilhões de habitantes, é um palco fisicamente heterogêneo onde são faladas 6.912 línguas e onde há 4.800 religiões só no Brasil. Esses dados, por si só, nos balizam a grande diversidade étnica, cultural, religiosa e técnico-científica. No entanto existem, seguramente, em todos os seguimentos da humanidade, atividades que, embora praticadas em locais distantes e por povos distintos, apresentam traços comuns.

Paradoxalmente, a unidade dentro dessa diversidade traz em seu bojo uma singular peculiaridade: a esperança de se compreender melhor a si próprio e o mistério da origem de todos os mistérios, buscando retirar o véu daquilo que se encontra oculto em linguagem muitas vezes cifrada, recheada 
de senhas e códigos secretos, peculiar a toda cultura. Daí por que o cultivo do mistério em suas diversas tonalidades configura um fenômeno religioso complexo e antigo. A prova disso é que "houve no passado e há ainda hoje sociedades humanas que não têm ciência, nem arte, nem filosofia. Mas não existe nenhuma sociedade sem Religião" (BERGSON, 1984, p. 105).

Segundo uma observação tomada de empréstimo de Moser (2009),

neste momento tão ímpar da história, nunca como agora o mistério sugerido por Michelangelo na monumental pintura da Criação que se encontra na Capela Sistina, em Roma, se colocou com mais força [...] é urgente tentar entrever o sentido do espaço deixado entre o indicador de Adão e o indicador de Deus. O artista sugere, ao mesmo tempo, distância e proximidade, semelhança e diferença.

É nesse pequeno e misterioso espaço que se coloca a transparente linha tênue mediadora (por meio do sopro-espírito) de carne e espírito, humanidade e divindade.

Aliado a isso, no centro dos debates sobre educação, é premente situar a importância que a espiritualidade desfruta, sobretudo para o que se poderia designar educação integral. Até porque a espiritualidade, como dimensão educativa, reconhecida ou não, está implicitamente presente na escola, chegando a ser um aspecto do currículo oculto. Talvez pudéssemos dizer que tal dimensão está ancorada no ethos religioso, expressando, assim, mais que um simples conceito.

Como assinala Moser (2004, p. 18),

o ethos acena para algo de mais profundo e decisivo [...] evoca 'ninho', 'casa', 'refúgio', 'identidade', 'consciência', 'a eterna e misteriosa morada do Ser', lá onde os seres humanos podem encontrar-se em profundidade com 'O SER', e por isso, consigo mesmos.

Talvez esse seja um dos motivos que finalmente levou a antropologia cultural a conferir ao fenômeno religioso um caráter universal, suplantando, em grande medida, uma tentativa mal costurada de decretar a morte de Deus, que, por algum tempo, provocou uma febre de ateísmo e secularização a partir do século XX. 
Estamos hoje às voltas com um despertar religioso em todo mundo: "este fato condicionador e formulador de novas projeções sociais, políticas, econômicas e culturais" (JENKINS, 2004, p. 18).

Sobre esse retorno efervescente do sentimento religioso, Bigheto e Incontri ressaltam que:

de todos os fenômenos humanos, o religioso é tão importante e fecundo que está na base de todas as culturas e é um fenômeno que abarca a humanidade toda e resiste a tentativas intensas de doutrinação materialista (veja-se o resultado de 70 anos de pregação materialista na extinta União Soviética). Nas palavras de Bobbio: "O homem continua sendo um ser religioso, apesar de todos os processos de demitização, de secularização e de todas as afirmações da morte de Deus, característico da idade moderna e, sobretudo, da idade contemporânea" (BIGHETO; INCONTRI, 2003).

Em contrapartida, assistimos ao tumultuado retorno do Ensino Religioso (ER) na escola pública. O artigo 19 da Constituição Federal do Brasil qualifica o Estado como laico. Entretanto, prevê no capítulo da educação, por meio da LDB (Lei n. 9.394/1996), a obrigatoriedade desse componente curricular no ensino fundamental, deixando facultativa a presença do aluno (art $210 \S 1^{\circ}$ ); delegando aos sistemas estadual e municipal de ensino competência absoluta para dispor sobre os conteúdos e a forma de executar a disciplina (JUNQUEIRA, 2007).

Posteriormente, para tentar dirimir algum equívoco que redundava em contradições e lacunas, o próprio Executivo assumiu, então, a responsabilidade de alterar o art. 33 por meio de um projeto de lei, originando a Lei n. 9.475/97.

Em conformidade com a referida Lei, presenciamos ao acelerado estágio de expansão e execução do ER nas escolas, tornando imprescindível que, na ordem dos diálogos sobre ER, deverá figurar um cuidadoso exame de questões cruciais para sua efetiva implementação, tais como:

- executar um projeto de ER apropriado ao caráter laico do Estado;

- ajustar o ER à diversidade de conteúdos curriculares, posturas políticas e crenças religiosas que assistem a escola;

- quais conteúdos e métodos escolher. 
Isso posto, naturalmente crescem as proposições que circundam o ER, explicitando a relevância da decomposição de um tema dessa envergadura, conferindo-lhe um friso de legítima precaução, pois, como assinala Daniel:

afinal, a educação desempenha uma função importante na maneira como as sociedades criam e transmitem crenças, valores, percepções e interpretações sobre muitos aspectos de nossas vidas, incluindo questões de conflito, paz e violência.

Não obstante, há muito por fazer para incrementar a tomada de consciência do papel da educação, quando esta transmite mensagens que debilitam ou fortalecem nossa capacidade de viver juntos (DANIEL, 2002, p. 22).

Desse modo, a dimensão fundante para nossa reflexão consiste em repensar o ER como um fecundo terreno para se recuperar, refletir e desenvolver, de forma plural e universal, a categoria "espiritualidade trabalhada" como conteúdo e estratégia didática.

\section{A sintonia com os cúmplices teóricos: reciprocidades e entrelaçamentos}

\section{Por que espiritualidade?}

Prosseguindo nossa reflexão sobre o conceito de espiritualidade, detectamos reciprocidade e entrelaçamentos entre Paul Tillich e Rafael Yus, enriquecendo significativamente o debate educativo.

Yus atribui grande valor à questão da espiritualidade para se alcançar os verdadeiros objetivos da educação holística, a qual se traduz na educação integral do ser humano por englobar as dimensões física, mental, emocional e espiritual do homem. Para esse pensador, "a espiritualidade se refere à nossa verdadeira natureza, o eu que está profundamente conectado a uma realidade espiritual maior, que vai além de nós mesmos" (YUS, 2002, p. 110). O autor prossegue postulando que:

a ausência da dimensão espiritual é um fator crucial no comportamento autodestrutivo. O abuso de drogas e do álcool, a sexualidade vazia, o 
crime e a ruptura familiar, tudo é fonte de uma busca errada de conexão, do mistério e do significado, e uma fuga devido ao pânico de não ter uma fonte autêntica de plenitude (YUS, 2002, p. 263).

O teólogo e filósofo teuto-americano Paul Tillich (2005), um dos mais expressivos pensadores do século XX, alega que subjacente às manifestações culturais se faz presente a espiritualidade humana, revelando o incondicionado propiciando manifestações especiais que se expõem enquanto cultura. $\mathrm{O}$ autor constrói uma rica correlação entre cultura e religião, salientando que nas expressões culturais ressoam conteúdos espirituais da vida que exprimem o sentido último e mais profundo da existência, a espiritualidade humana. Daí porque é incisivo em afirmar que o homem é um ser naturalmente religioso.

Ao investigar sobre a situação do homem na sociedade moderna, tal autor constata que a perda da dimensão de profundidade, isto é, da dimensão religiosa, da espiritualidade, causa danos profundos.

Essa verificação leva-nos a inferir que a ausência dessa propriedade humana responde, em grande parte, pela condição paradoxal de nossa evolução como espécie quando da fragmentação em todas as esferas da vida humana, compartimentalizada e padronizada, que levou a humanidade a desenvolver uma visão materialista, individualista, carente de espiritualidade, logo, contrariando um princípio vital para o ser humano.

Podemos inferir que a dimensão espiritual, como elemento constitutivo do ser humano, deve ser eleita como uma experiência do sagrado na profundidade e totalidade do ser humano, perpassando a história da humanidade, extrapolando, assim, os domínios do senso comum que a limita apenas aos contornos da instituição religiosa. Portanto, entendemos que essa categoria não pode ser negligenciada ou omitida se advogarmos pelo desenvolvimento de uma educação integral de nossos alunos.

\section{Olhares científicos da nova biologia, da genética e da neurociência}

Ampliando um pouco mais a questão, encontramos um artigo de argumentação vigorosa, "Deus e a espiritualidade sob olhares científicos 
pós-modernos: limites e possibilidades da nova biologia, da genética e da neurociência no campo da(s) ciência(s) da religião" (QUEIROZ, 2009). Ao realizar um grande inventário sobre o assunto, nos dando visão clara e atualizada, além de nos proporcionar uma indicação bibliográfica riquíssima, o artigo se apresenta como um convite a estudar atentamente o campo de investigação ainda embrionário da biologia, da genética e da neurociência, em busca de Deus e da experiência religiosa, mediante a apresentação de um grande movimento das ciências naturais para explicar os fundamentos biológicos e neurobiológicos da espiritualidade e das experiências religiosas.

Seguramente, reside nessas pesquisas científicas um importante ponto de partida, abrindo fronteiras para se repensar o Ensino Religioso.

Para nossa reflexão, centrada no tema do encontro pedagógico entre espiritualidade e educação, o artigo de David Hay e Paul Socha (2002), "O olhar da ciência para a espiritualidade", é de grande relevância. Ao buscar na fundamentação empírica a prova de que a espiritualidade está sustentada biologicamente, e não decorre da construção social, os cientistas desvelam a existência de uma dimensão holística da experiência humana e postulam, a partir de então, uma ética comum e um sentimento de imanência quando da vivência de uma experiência religiosa.

Um outro trabalho merece destaque. O geneticista norte-americano Dean Hamer, autor do livro O Gene de Deus: como a herança genética pode determinar a fé, ${ }^{1}$ busca comprovar a presença de um gene responsável por uma predisposição à crença que ele atribui como sendo de espiritualidade. $O$ gene isolado pelo geneticista e sua equipe, no Instituto Nacional de Câncer, nos EUA, é identificado pela sigla VMat2, de evidências ainda insuficientes, contudo fortes o bastante para defender a teoria do gene divino e postular a universalidade do fenômeno da "autotranscendência" de Cloninger, ${ }^{2}$ mediante a apresentação de um fundamento empírico que o justifique. Em suas conclusões, o estudioso afirma que as características de espiritualidade estão presentes em todos os sujeitos, portanto, levam a crer na hereditariedade, na existência de um fator genético.

1 HAMER, D. 0 gene de Deus. São Paulo: Mercuryo, 2005.

2 CLONINGER apud HAMER, 2005, p. 23. 
O pesquisador alerta para a importância de não se confundir espiritualidade com religião, pois a espiritualidade diz respeito aos sentimentos interiores das pessoas, enquanto a religião refere-se a um conjunto organizado de regras e regulações. A espiritualidade refere-se a como as pessoas se sentem a respeito de deus, ou qualquer que seja o criador, enquanto a religião trata especificamente sobre quem é esse deus e como ele age.

Adicionalmente, recorremos a Raul Marino Junior (2005), que, ao valer-se de uma rica bibliografia atualizada, advoga em favor de uma neuroteologia com a obra A religião do cérebro. As novas descobertas da neurociência a respeito da fé humana. Ao partir das conclusões de pesquisas já publicadas, sua proposta se firma na esteira de estudos clássicos da genética e da neurociência. Das conclusões levantadas pelo pesquisador, destacamos um ponto estrutural de suas investigações, a saber: no cérebro está a sede da espiritualidade e a chave dos mistérios.

Como fora sublinhado anteriormente, essas pesquisas são ainda embrionárias, já que, embora apresentem auspiciosas possibilidades, devem ser cercadas de limites e preocupações epistemológicas contundentes. Contudo, nossa contribuição nesta exposição, destinada, sobretudo, a pretender ser uma justificativa em favor da espiritualidade como categoria de ensino, nos permite considerar que os resultados alocados das pesquisas acondicionam elementos para, num golpe de vista superficial, nos dar a certeza de uma nova ponte em construção, um novo momento de diálogo e abertura, ou mesmo provocar, inquietar, incomodar, esgarçar as barreiras étnicas e religiosas que gravitam em torno do ER que insiste no caráter confessional.

\section{Olhar da UNESCO}

Para consolidar de modo contundente a nossa tese acerca da categoria "espiritualidade" como valiosa dimensão educativa, abordaremos a seguir o que fala a Declaração Universal sobre Diversidade Cultural, elaborada pela UNESCO em Conferência Geral, em 02/11/2001. Em tal declaração reafirma-se que: 
a cultura deve ser considerada como o conjunto de traços distintivos espirituais e materiais, intelectuais e afetivos que caracterizam uma sociedade ou um grupo social e que abrange, além das artes e das letras, os modos de vida, as maneiras de viver juntos, os sistemas de valores, as tradições e as crenças (DECLARAÇÃO, 2002).

No artigo três, versando sobre a diversidade cultural como fator de desenvolvimento, esse órgão internacional assevera que:

a diversidade cultural amplia as possibilidades de escolha que se oferecem a todos; é uma das fontes do desenvolvimento, entendido não somente em termos de crescimento econômico, mas também como meio de acesso a uma existência intelectual, afetiva, moral e espiritual satisfatória (DECLARAÇÃO, 2002).

Ainda, como um dos objetivos a ser endossado para aplicação do plano de ação da referida Declaração, destaca-se a necessidade de: "promover, por meio da educação, uma tomada de consciência do valor positivo da diversidade cultural e aperfeiçoar, com esse fim, tanto a formulação dos programas escolares como a formação dos docentes" (DECLARAÇÃO, 2002).

Até aqui, buscamos fundamentar teoricamente que o ER, para ser profícuo, deverá se pautar em princípios que levem em consideração a pluralidade religiosa como um fator cultural inegável, e dessa pluralidade é possível resgatar um elemento comum, a saber, a espiritualidade, princípio ativo de toda manifestação religiosa, logo, ponto de partida para se iniciar o diálogo inter-religioso sem atrelar a dogmas religiosos.

Nesse sentido, é oportuno acrescentar uma belíssima constatação de Panikkar sobre religião, cultura e linguagem:

não há religião sem linguagem e a linguagem é já cultura. A religião dá à cultura seu conteúdo e a cultura dá à religião sua linguagem própria. Daí que a relação entre religião e cultura seja constitutiva para ambas e que, em conseqüência, devamos reconhecer:

*que não há religião sem cultura e nem cultura sem religião;

*que a experiência de Deus não é um monopólio de nenhum sistema religioso - com este e outro nome -, de nenhuma igreja e, no fundo de nenhuma cultura; 
*que necessitamos da mediação de uma linguagem e a linguagem é já um fenômeno cultural. Por conseqüência, todas as nossas concepções acerca de deus, assim como nossa memória, nossa interpretação e a recepção que fazemos da experiência estão mediatizadas por uma concepção, por uma crença, ou por uma religião. Não se pode separar, mas se devem distinguir (PANIKKAR, 2007, p. 57-58).

\section{Construção, desconstrução, reconstrução do conhecimento: uma nova perspectiva para 0 ER}

\section{Base epistemológica}

Em conformidade com nossos anseios educacionais, encontramos, nas ciências da religião, a base epistemológica adequada para sustentar e direcionar nossa proposta pedagógica de ER.

Essa abordagem possibilita a análise diacrônica e sincrônica do fenômeno religioso, a saber, o aprofundamento das questões de fundo da experiência e das expressões religiosas, a exposição panorâmica das tradições religiosas e as suas correlações socioculturais. Trata-se, portanto, de um enfoque multifacetado que busca luz na Fenomenologia, na História, na Sociologia, na Antropologia e na Psicologia da Religião, contemplando, ao mesmo tempo, o olhar da Educação. Além de fornecer a perspectiva, a área de conhecimento das Ciências da Religião favorece as práticas do respeito, do diálogo e do ecumenismo entre as religiões. Contribui desse modo, com uma educação de caráter transconfessional que poderá incidir na formação integral do ser humano (SOARES, 2007, p. 8-9).

Essa abordagem parece estar em conformidade com o ser humano, que é simultaneamente múltiplo, logo, multifacetado. Desse modo, é essencial que a educação de modo geral, e em especial o ER, tome conhecimento da complexidade humana que resulta da condição humana na era planetária, infelizmente, caracterizada por desenvolver-se na e pela violência, destruição, exploração, etc.

Morin (2001a) nos alerta para esse fato aferindo que "aquilo que porta o pior perigo traz também as melhores esperanças: é a própria mente 
humana, e é por isso que o problema da reforma do pensamento tornouse vital".

Daí porque se torna imperativa a reforma do pensamento sobre o modelo de ER, baseado numa educação para a compreensão humana, como missão espiritual da educação. Essa missão busca a solidariedade intelectual, espiritual e moral da humanidade.

Assim, fica claro que, ao postularmos as ciências da religião como base epistemológica para o ER, torna-se premente frisar que essa área científica se afina com a epistemologia atual.

O epistemólogo e sociólogo francês Edgar Morin, considerado um dos mais importantes pensadores contemporâneos, elaborou a Teoria da Complexidade. Por meio de um método interdisciplinar de análise da realidade, sua proposta pauta-se na reforma do pensamento e na "reconstrução dos saberes"3 como caminho para compreender e administrar a complexidade, reestruturando-se a "ecologia das ideias" sobre o universo na mente dos seres humanos: o cósmico, o humano, o histórico componente da mesma realidade, que pode ser estudada e observada a partir de diferentes ângulos, complementares e interdependentes.

Essa teoria acena-nos para a seguinte possibilidade:

o novo horizonte epistemológico, que requer e admite a pluralidade de saberes, abre a possibilidade e a necessidade do estudo da experiência religiosa, tendo em vista que ela entrou com força na aldeia global e constituise como um dos componentes sociologicamente mais relevantes [...]. O ER nas escolas pode e deve tornar-se uma disciplina para a formação integral do aluno e da sua cidadania (COSTELLA; OLIVEIRA, 2007, p. 46-47).

Decorrente dessa epistemologia, acreditamos que a prática do componente curricular ER deverá ancorar-se nos seguintes pressupostos:

- na aceitação da dimensão espiritual do ser humano e na conscientização do retorno ao sagrado, revelado, entre outras formas, por meio das novas e diversas manifestações de espiritualidade, inclusive, da inusitada espiritualidade laica;

3 Cf. MORIN, 2001b, p. 559-567. 
- a prática do ER, para estar em sintonia com a epistemologia contemporânea delineada pelo pensamento da complexidade e da religação dos saberes, deverá resguardar a alteridade no intuito de se erradicar a intolerância, o fanatismo, o fundamentalismo para defender o respeito ao outro como via de se alcançar a unidade na diversidade;

- buscar na categoria espiritualidade, que permeia as interfaces do sagrado, o genuíno conteúdo de ensino, haja vista que essa dimensão humana representa um ponto comum entre as diversas correntes religiosas. Nesse sentido, a espiritualidade poderá representar a ampliação de conhecimento do aluno, não a sua recusa e alienação;

- ao partir desse pressuposto, caberá ao professor trabalhar conteúdos sob ângulos tão dinâmicos e mutáveis quanto o é a própria realidade e, ainda, quanto o é a própria espiritualidade;

- detectar na categoria espiritualidade uma fecunda estratégia didática e, sim, uma técnica que estimule e favoreça a motivação do aluno para a reflexão sobre o espiritual;

- acreditamos nessa premissa que a angústia existencial é um fato concreto que vêm de longa data instigando o homem a buscar, na transcendência, respostas para o sentido da vida. Logo, a espiritualidade parece-nos ser um elemento bastante representativo para o ser humano.

Sobre isso, Leonardo Boff (2009), em seu artigo "Espiritualidade, dimensão esquecida e necessária”, faz uma incursão sobre a interpretação da espiritualidade humana, descortinando uma realidade que sinaliza o aspecto reducionista e de senso comum incorporado nesse conceito. Ao pontuar sobre o tema o autor assevera:

espiritualidade vem de espírito. Para entendermos o que seja espírito precisamos desenvolver uma concepção do ser humano que seja mais fecunda do que aquela convencional, transmitida pela cultura dominante. Esta afirma que o ser humano é composto de corpo e alma ou de matéria e espírito. [...] Perdeu-se a unidade sagrada do ser humano vivo que é a convivência dinâmica de matéria e de espírito entrelaçados e inter-retro-conectados.

O autor rejeita qualquer tipo de fragmentação do ser humano, posto que o homem constitui uma totalidade complexa, uma sinfonia de múltiplas 
dimensões. Segundo o autor, três dimensões são fundamentais do ser humano: a exterioridade humana expressa na corporeidade; a interioridade constituída pelo universo da psique. $\mathrm{O}$ autor compreende que a interioridade é denominada também de mente humana, entendida como totalidade do ser humano voltada para dentro, captando todas as ressonâncias que o mundo da exterioridade provoca dentro dele.

Entendida como um modo de ser, uma atitude de base a ser vivida em cada momento e em todas as circunstâncias, essa espiritualidade não pode ser esquecida, pois é necessária para uma vida harmônica e saudável. O autor completa dizendo que "a espiritualidade exorciza o complexo mais difícil de ser integrado: o envelhecimento e a morte" (BOFF, 2009).

\section{Pressuposto teórico filosófico}

Em consonância com uma proposta de ER pertinente ao caráter laico do Estado, à pluralidade religiosa e a diversidade cultural e aos avanços das ciências naturais, fica ecoando em nossa mente a questão do encontro de diferentes posturas religiosas, crenças e convicções de fé. Afigura-se aí, uma situação inusitada, em que a sensibilidade e a criatividade devem perpassar esse processo para daí buscar o verdadeiro sentido da atividade.

Corolários dessa necessidade buscam, na filosofia da educação de Alfonso Lopes Quintás, o norte estimulador para acreditar em tal possibilidade.

Gabriel Perissé, em seus estudos sobre A. L. Quintás, nos traz importantes elucidações a respeito dessa filosofia. Nas palavras do intérprete:

a filosofia da Educação de A.L.Q. não implica somente uma busca adequada entre sujeito e realidade em busca do conhecimento. Supõe e incentiva, com um otimismo epistemológico conquistado pela pesquisa (em compromisso com a abertura do espírito para a realidade), uma recepção ativa, um diálogo. Um diálogo vivo que haverá de desembocar no entusiasmo decorrente do conhecimento significativo, provocado pela descoberta de sentido, despertado pela riqueza interior que se experimenta no momento em que um conceito vem à luz, em que nasce uma convicção, em que surge uma compreensão nova da realidade (PERISSÉ, 2004, p. 24-25). 
A noção de encontro é fundamental para compreender o pensamento de Quintás. Daí a compatibilidade de nossa compreensão acerca do ER, pois entendemos que o conhecimento no ER deve ocorrer por meio do encontro do sujeito com o outro, com a natureza, com o diferente, com a arte, com a literatura, com a metáfora, com o transcendente e consigo mesmo.

Sobre o conceito de encontro, como elemento-chave para compreender e vivenciar a proposta filosófica e pedagógica de Lopes Quintás, Perissé salienta que:

na base do encuentro, vemos uma atitude relacional de fundo, uma atitude própria da nossa condição pessoal. [...] López Quintás define a pessoa como uma racionalidade dialógica, ou seja, há no ser humano uma abertura criadora, uma capacidade de interagir e de fundar uma abertura criadora, uma capacidade de interagir e de fundar relações, capacidade que se expressa sobretudo na linguagem. A linguagem como expressão do diálogo, do amor que conhece, e que faz surgir campos de realidade, cria âmbitos, levando as pessoas envolvidas nesse diálogo - o professor e os alunos envolvidos nesse diálogo vivo - a tomar consciência do seu valor como seres inteligentes, criativos, livres, convocados à plena realização (PERISSÉ, 2004, p. 27).

Assim, podemos gerir uma proposta de ER em que a diversidade e o pluralismo religioso representam o âmbito, que na filosofia quintasiana significa "toda realidade dinâmica aberta, capaz de estabelecer diálogo com outras realidades, originando novas e irredutíveis realidades" (PERISSÉ, 2004, p. 35-36).

Desse modo, o campo de encontro para a integração dinâmica entre as diferentes manifestações religiosas nos possibilitará um Ensino Religioso criativo, em que todos possam comungar a experiência, o conhecimento e a sensibilidade uns dos outros.

\section{Pressuposto teórico metodológico para uma transposição didática}

Vale ressaltar que nosso intento extrapola o nível teórico da discussão, visto que pretendemos avançar no sentido de se traçar uma metodologia 
de ensino que assegure princípios valorosos, como, por exemplo, pleitear uma educação para a paz que transite de forma harmônica no campo plural, ou seja, na perspectiva do "pluralismo religioso"(SANCHES, 2005), para o campo universal, a dimensão espiritual inerente ao ser humano rumo a um processo de humanização por meio do diálogo inter-religioso.

Todavia, é preciso inquirir: isso basta? Como efetivar uma transposição didática que contribua para a ocorrência de uma aprendizagem significativa do aluno?

Diante de um tema gerador de tantas preocupações, buscamos, nos princípios fornecidos pela psicologia da educação, o respaldo científico para se pensar e rever a questão da organização e transmissão de conteú$\operatorname{dos}^{4}$ no ER. O contato com a literatura específica permitiu-nos encontrar a abordagem que destacasse a questão em pauta: os princípios teóricos do cognitivista David Ausubel servirão de subsídio para desenvolver a presente proposta de transposição didática para o ER.

\section{Proposições teóricas de D. Ausubel}

O fator isolado mais importante que influencia a aprendizagem é aquilo que o aprendiz já sabe. Descubra o que ele sabe e baseie nisso os seus ensinamentos (AUSUBEL, 1980, p. 34).

Apresentaremos, de forma concisa, apenas algumas das proposições teóricas ausubelianas acerca da aprendizagem significativa mais apropriada para explicar nosso parecer sobre a transmissão dos conteúdos de ER.

\section{Tipos de aprendizagem}

Ausubel fala em diferentes tipos de aprendizagem, contudo focaremos apenas a aprendizagem significativa.

4 SMARJASSI, 1996, p. 15. 
Para Ausubel, a aprendizagem significativa é caracterizada como um processo por meio do qual uma nova informação se relaciona com um aspecto relevante da estrutura cognitiva de um indivíduo. A ocorrência desse tipo de aprendizagem depende da nova informação ancorar-se em conceitos relevantes, preexistentes na estrutura cognitiva de quem aprende. A possibilidade de um conteúdo adquirir sentido depende dele ser incorporado a um conjunto de conhecimento existente na estrutura mental do sujeito. $O$ fator isolado mais importante é o que o aprendiz já sabe.

Podemos inferir, a partir dessa constatação, que o conhecimento prévio representa o ponto de partida para se perseguir uma aprendizagem significativa. Daí porque insistimos na categoria "espiritualidade" como ponto de partida e de desenvolvimento de todo percurso das aulas de ER.

\section{Tipos facilitadores de aprendizagem significativa}

Ausubel apresenta três importantes tipos de materiais facilitadores da aprendizagem significativa.

Os organizadores prévios são materiais introdutórios caracterizados por serem claros e estáveis. Sua principal função é estabelecer uma ponte entre o que o aprendiz já conhece e o que ele precisa conhecer. Para tanto, "visa focalizar a atenção do aprendiz em elementos ou atributos de materiais de estudos que poderiam passar inteiramente despercebidos" (NOVAK, 1981, p. 63).

Segundo Ausubel, os organizadores prévios são de dois tipos: os expositivos, usados para introduzir materiais bem desconhecidos, fornecendo os subsunçores relevantes; os comparativos, usados tanto para integrar novas ideias com conceitos basicamente similares (preexistentes) quanto para aumentar a discriminação entre novas ideias existentes, essencialmente diferentes, mas confusamente similares.

Nesse ponto, parece oportuno deixar explícito o porquê de alegarmos que a espiritualidade pode ser contemplada como um material facilitador da aprendizagem significativa no ER. Essa estratégia didática, de partir da experiência do aluno para introduzir novos conteúdos a respeito do tema, favorecerá o conhecimento de novas e diferentes formas de se 
viver a espiritualidade. Assim, por meio de um processo de exposição e comparação, seu conhecimento poderá aprofundar-se e tornar-se mais rico e interessante para o aluno.

A reconciliação integrativa consiste em explicar certas relações entre ideias, ressaltar suas similaridades e semelhanças, e reconciliar inconsistências reais ou aparentes.

Para atingir com maior certeza uma reconciliação integrativa, devemos organizar a instrução de modo a fazer um 'sobe-desce' nas hierarquias conceituais à medida que novas informações são apresentadas. Podemos começar satisfatoriamente com os conceitos mais gerais, mas é preciso ilustrar logo como os conceitos subordinados estão a eles relacionados, e então voltar através de exemplos, a novos significados para conceitos de ordem superior (NOVAK, 1981, p. 70-71).

A diferenciação progressiva é um outro facilitador. Segundo Ausubel, a programação das matérias a serem ensinadas deve seguir uma hierarquia. As mais gerais e inclusivas são apresentadas no início e progressivamente, diferenciadas em termos de detalhes e especificidade.

Em nossa proposta, deixamos claro que o conceito de espiritualidade é o mais geral, e é a partir dele que passaremos a diferenciar as inúmeras formas (monoteísta, politeísta, ateísta) de viver a espiritualidade.

Para esclarecer melhor como isso é possível, recorremos às reflexões teóricas de diferentes autores sobre espiritualidade.

L. Boff sublinha que a experiência espiritual não está necessariamente atrelada a doutrinas e crenças, mas a uma questão de atitude. Acrescenta ainda, que a espiritualidade é um processo em constante desenvolvimento. Portanto,

para ter e alimentar espiritualidade a pessoa não precisa professar um credo ou aderir a uma instituição religiosa. A espiritualidade não é monopólio de ninguém, mas se encontra em cada pessoa e em todas as fases da vida. Essa profundidade em nós representa a condição humana espiritual, aquilo que designamos espiritualidade (BOFF, 2009).

Em semelhante interpretação, Mariá Corbí postula que a verdade espiritual silenciosa não pode ser substituída por instituições religiosas ou deuses. 
Em sua proposta para uma espiritualidade laica, esse autor explicita em sua entranha um anseio de reconciliação universal fazendo ecoar a seguinte exortação:

nas novas sociedades globais a espiritualidade não pode passar por crenças que se proclamam exclusivas possuidoras da verdade e que, por isso, excluem toda outra verdade. Cada tradição espiritual poderá utilizar suas expressões, formulações, signos e rituais com humildade, sem colocá-las acima das outras tradições. Cada uma das tradições pode ser plenamente verdade sem que deva considerar-se a si mesma como única e exclusiva. Com o mesmo empenho e amor com que segue a verdade haverá que evitar a agressão a outras tradições, não somente física, senão mental ou de coração. Terá que abolir a pretensão de desprestigiar as outras tradições e ficar longe das piores tentações: a de ignorar as outras tradições, pois ignorá-las é ofensa e desprezo (CORBÍ, 2007, p. 322).

Comte-Sponville (2007, p. 125), outro teórico ateu, delega à espiritualidade um atributo peculiar do ser humano. Não obstante, é incisivo em equacionar a tese que aponta a religião e a inreligião como um direito a ser assegurado pela sociedade igualitária. Decorre dessa singular equação o dever de "proteger ambas (inclusive uma contra a outra, se necessário) impedindo ambas de se imporem pela força".

O que fica patente diante de tais prerrogativas é que a espiritualidade é uma dimensão humana consagrada tanto por ateus quanto por monoteístas e politeístas e, como tal, pode e deve proporcionar ao ser humano experiências de crescimento e harmonia com o cosmos.

\section{A transposição didática}

Passaremos a delinear o esboço de uma proposta de transposição didática para o ER com o objetivo de buscar uma identidade pedagógica para esse componente curricular.

A transposição didática no ER deverá privilegiar as ferramentas que permitam aos alunos expressar sua criatividade. É importante procurar adicionar elementos provocadores que suscitem a curiosidade, intriguem, 
interessem; é o aluno que constitui, pouco a pouco, seu conhecimento; ele deve se interessar pelo assunto.

Nossa proposta se realizará conforme os seguintes passos:

- apresentação de um organizador prévio por meio da elaboração de um caleidoscópio, visando a observar e a explorar a diversidade na unidade;

- leitura e discussão sobre o artigo da constituição versando sobre o ER;

- levantamento dos conceitos prévios (representações) dos alunos sobre espiritualidade.

Sobre esse passo, Nouailhat (2004) vem contribuir afirmando a necessidade, neste momento, de inquirir sobre o que os alunos "têm na cabeça", sobre o assunto e o que acontece com eles quando o trabalhamos (o assunto). Essa pesquisa permite o levantamento de dois tipos de elementos:

- os elementos supostamente assimilados anteriormente dentro do curso escolar, os "pré-requisitos" ou fundamentos - cuja necessidade para as novas aquisições está no âmbito dos conceitos que as tornarão inteligíveis;

- os elementos provenientes de outras esferas, as ideias já interiorizadas sobre o assunto, as "pré-aquisições" - sobre as quais se poderão ampliar o conhecimento ou retrabalhá-lo, caso ele esteja impregnado de preconceitos. É indispensável estabelecer o diagnóstico sem se esquecer o quanto ideias "falsas" funcionam como "verdadeiras"; a força com a qual elas podem se arraigar, sobretudo, no campo religioso; elas correspondem, para aqueles que as têm em mente, ao seu "modo de ver"; essas representações são suas realidades, histórias e razões.

Um primeiro levantamento das representações pode ser feito de forma bastante simples, a partir de qualquer fato religioso: por exemplo, ao redor de palavras como "credo", "ritual sagrado", "procissão", "relíquias", "livro sagrado", "guru”, "templo”, "calvário”, "ascese”, etc. 
- Estimular a pesquisa exploratória, por meio de entrevista na comunidade sobre espiritualidade.

- Apresentação de um texto (anexo n. 1), preferencialmente científico, sobre espiritualidade.

- Elaboração do conceito de espiritualidade a partir da contribuição dos alunos.

- Retomar o texto sobre espiritualidade e identificar os conceitos imanentes do conceito geral e organizar com os alunos o mapa conceitual, ressaltando a diferenciação progressiva e a reconciliação integrativa entre os conceitos mais gerais e inclusivos e os conceitos subordinados, menos inclusivos.

A hipótese até aqui defendida e que será ampliada a seguir é a de que a dimensão espiritual do ser humano não pode ser confiscada por um único segmento religioso. A relação do ser humano com o Absoluto ultrapassa fronteiras. Por exemplo, o texto (anexo n. 1) apresentado como organizador prévio, deixa claro que dentro do monoteísmo é possível encontrar diferentes experiências espirituais em que as pessoas mergulham na realidade divina e realizam seu encontro pessoal com o Sagrado, com o Transcendente, enfim, com Deus de diversos modos. Aprofundando um pouco mais, observamos que dentro do cristianismo, do judaísmo e do islamismo, religiões monoteístas mais conhecidas, vamos encontrar incontáveis grupos dissidentes dessas raízes religiosas e, consequentemente, entender que cada uma delas tem sua forma peculiar de viver a experiência espiritual.

Voltemos ao exemplo dos três monoteísmos. René Nouailhat (2004), no capítulo V "Uma Pedagogia em quatro tempos", nos mostra que o conhecimento de cada uma das religiões, suas dimensões mitológicas (seus grandes mitos), históricas (principais momentos de sua construção), doutrinais (afirmações fundamentais); suas organizações e práticas (cultos, rituais, devoções); suas grandes obras (notadamente artísticas) dentro da história das civilizações; suas pluralidades, complexidades e evoluções (suas partes mortas, seus elementos vivos; suas recuperações e sincretismos); seus encontros atuais (violentos ou pacíficos), mediante o mero fato de abordar essas três religiões em suas influências recíprocas e dentro de seus contextos próprios (quer dizer, dentro do campo de outras 
influências e dentro de seus diferentes níveis de constituição) evitam não somente uma aproximação demasiadamente exclusiva, mas também certas ingenuidades que alimentam as atitudes fundamentalistas ou sectárias.

- Apresentar um quadro conceitual explicitando parcialmente os desdobramentos do conceito espiritualidade, lembrando que em cada desdobramento se constrói uma maneira diversa de se viver essa experiência.

É importante observar que do conceito mais geral e inclusivo de espiritualidade decorrem os diferentes tipos de se vivenciar essa experiência, como, por exemplo, no monoteísmo, no politeísmo, no ateísmo e assim sucessivamente:

- um outro momento será reservado para identificar, via pesquisa, outras possíveis maneiras de expressar ou viver a espiritualidade;

- identificar os pontos nucleares de cada forma de espiritualidade, detectar pontos convergentes e divergentes;

- levantamento estatístico das religiões representadas na cidade, na escola e na classe;

- apresentar o texto "A idade da águia" (anexo n. 2) e estimular os alunos a refletir sobre as possibilidades de se meditar sobre espiritualidade em diferentes prismas religiosos.

É premente esclarecer que o texto a ser utilizado como recurso didático evidencia o quanto a metáfora é linguagem dominante da espiritualidade, daí por que seu poder de alcance nos surpreende.

Cassirrer (2006, p. 54) constata que a metáfora nos reconduz "à forma fundamental da conceituação verbal". Desse modo, fica patente que esse tipo de recurso é importante para compor uma proposta de transposição didática da categoria espiritualidade no ER.

David Tracy corrobora essa premissa com a seguinte constatação:

o fato de todas as grandes religiões se fundarem em certas metáforas básicas tornou-se um lugar-comum nos estudos religiosos modernos. Numa 
religião específica as metáforas básicas formam um conglomerado ou redes em que certas metáforas recorrentes tanto organizam metáforas subsidiárias quanto difundem novas. Essas redes descrevem o enigma e a promessa da situação humana e prescrevem certos remédios para essa situação (TRACY, 1992, p. 95).

Assim, por meio do uso da metáfora, podemos "correlacionar certos significados e verdades em particular de nossa experiência humana e linguagem comum com os significados e verdades interpretadas de uma tradição religiosa específica" (TRACY, 1992, p. 96).

- Estimular os alunos a manifestarem sua experiência espiritual, se possível, destacar situações que marcaram de modo positivo e de modo negativo esse episódio.

- Estimular a elaboração de uma "feira da religiosidade" com exposição de livros sagrados, objetos de uso litúrgico, curiosidades sobre as diferentes religiões, disposição geográfica e histórica das religiões, bibliografia e ou documentários de grandes ícones espirituais.

- Redigir uma reflexão a partir do seguinte texto: "Não haverá sobrevivência sem uma ética mundial. Não haverá paz no mundo sem paz entre as religiões. E sem paz entre as religiões não haverá diálogo entre as religiões" (KÜNG, 2003, p. 7).

- Solicitar dos alunos uma devolutiva destacando os pontos positivos e negativos do projeto e sugestões para melhorar as aulas de ER.

\section{Considerações finais}

\section{Desdobramentos, essências e dimensões desveladas}

A procura por um significado mais relevante, menos parcial e mais abrangente para o ER está intimamente ligada à maneira que percebemos o “objetivo e o propósito" desse componente curricular proposto na legislação, pois nenhuma procura por significado e valor acontece no vácuo. Nossas buscas por um novo modo de trabalhar com o ER acontecem dentro de um 
contexto de envolvimento com uma cultura dominante que nos ventila possibilidades, mas também muitos limites. Entretanto, devemos reconhecer, ainda, que a cultura exerça influência sobre a maneira como percebemos tal busca. Essa mesma cultura também determina de forma bastante significativa como nossa procura por significado se desenrola. Como educadores, nossa trajetória, de procura por significados e valores, sugere que a dimensão holística e ética da existência humana é algo que não pode ser ignorado.

Por isso, a ideia dominante que permeou este artigo repousa na premissa de adotar a categoria espiritualidade no ER com o propósito de desenvolver uma educação cujo princípio é o de alimentar o crescimento potencial intelectual, emocional, social, artístico e espiritual do ser humano, abrindo portas que viabilizem aos alunos estabelecer pessoalmente o diálogo místico. Assim, buscamos enfatizar o conhecimento e a experiência por meio da conexão intrapessoal e transpessoal que a educação pode orientar para a experiência transcendental, de reverência à vida, atitude de respeito e de reverência ante a transcendência da gênese de nossa existência.

Oscilando entre limites e possibilidades, apresentamos como sugestão o embrião de um projeto de Ensino Religioso cujo modelo para transposição didática está fundamentado na Teoria de Aprendizagem Significativa de David Ausubel. ${ }^{5}$

Entretanto, guardadas as devidas proporções, três ordens de motivação nos conduzem a expor algumas considerações a título de prospecção. Em primeiro lugar, colocar em relevo a necessidade de verificação experimental mediante uma pesquisa mais ampla, desenvolvida em situações reais de sala de aula, a fim de se colher resultados mais precisos em relação à pertinência e alcance da proposta apresentada.

Em segundo lugar, é preciso considerar que o professor é um dos elementos mais importantes na mediação da tarefa educativa. Todavia, um grande limite se impõe à possibilidade de desconstrução, construção, reconstrução de uma nova proposta para se implantar o autêntico ER: trata-se, por exemplo, do aparente despreparo dos professores que atuam nessa disciplina, que, na maioria das vezes, são improvisados revelando um grande desafio a ser superado por meio de uma adequada habilitação desses profissionais.

5 AUSUBEL; NOVAK; HANESIAN, 1980. 
Assim, acreditamos ser oportuno e imprescindível registrar alguns objetivos essenciais para a implantação de cursos de licenciatura em ER propostos pelo Fonaper:

possibilitar ao profissional um referencial teórico-metodológico que propicie a leitura e a interpretação crítica e consciente do fenômeno religioso pluralista; habilitá-lo ao pleno exercício pedagógico mediante a busca da construção do conhecimento com base em categorias, conceitos, práticas e informações sobre o fenômeno religioso e suas conseqüências socioculturais no universo pluralista da educação; qualificá-lo pelo acesso ao conhecimento e à compreensão do fenômeno religioso presente em todas as culturas, para o exercício pedagógico, científico e religioso; possibilitarlhe o acesso aos direitos previstos nas legislações específicas do magistério (FONAPER, 1997).

Em terceiro lugar, advogamos em favor de se atribuir às ciências da religião a competência para conferir um vigor renovado à formação do professor de ER.

Desse modo, não fecharemos nossa reflexão, mas deixaremos em aberto um leque de questões a serem investigadas e aprofundadas com a responsabilidade e o rigor científico que o tema exige.

\section{Referências}

AUSUBEL, D. P.; NOVAK, J. D.; HANESIAN, H. Psicologia educacional. Rio de Janeiro: Interamericana, 1980.

BERGSON, H. Cartas, conferências e outros escritos. São Paulo: Abril Cultural, 1984. (Os Pensadores).

BIGHETO, A. C.; INCONTRI, D. 0 ensino inter-religioso, como fazer? 2003. Disponível em: 〈www.hotopos.com/mirandi15,25/01/2009〉. Acesso em: 25 jan. 2009.

BOFF, L. Espiritualidade, dimensão esquecida e necessária. 2009. Disponível em: <http://www.pjssc.kinghost.net/v9/modules/planet/view.article.php/461〉. Acesso em: 27 fev. 2009. 
BRASIL. Lei n. 9.394/96, de 20 de dezembro de 1996. Estabelece as diretrizes e bases da educação nacional. Diário Oficial [da] República Federativa do Brasil, Poder Legislativo, Brasília, DF, 23 dez. 1996. p. 27833. Disponível em: <http:// www6.senado.gov.br/legislacao/ListaTextoIntegral.action?id=75723>. Acesso em: 23 jul. 2009.

BRASIL. Presidência da República. Lei n. 9.475/97, de 22 de julho de 1997. Dá nova redação ao Artigo 33 da Lei n. 9.394/96, que estabelece as Diretrizes de Base da Educação Nacional. Diário Oficial [da] República Federativa do Brasil, Brasília, Congresso Nacional, 1997.

CASSIRER, E. Linguagem e mito. Tradução de J. Guinsburg e M. Scnaiderman. São Paulo: Perspectiva, 2006.

CORBÍ, M. Hacia una espiritualidad laica: $\sin$ creencias, sin religiones, sin dioses. Barcelona: Herder, 2007.

COMTE-SPONVILLE, A. 0 espírito do ateísmo: introdução a uma espiritualidade sem Deus. Tradução de Eduardo Brandão. São Paulo: Martins Fontes, 2007.

DANIEL, J. Posições/controvérsias - aprender a viver juntos: desafio prioritário no alvorecer do século XXI. In: BRASLAVSKY, C. (Org.). Aprender a viver juntos: educação para integração na diversidade. Tradução de José Ferreira. Brasília: UNESCO; IBE; SESI; UNB, 2002.

COSTELLA, D.; OLIVEIRA, E. T. Epistemologia do Ensino Religioso. Religião \& Cultura, v. 6, n. 11, p. 43-56, 2007.

DECLARAÇÃO universal sobre a diversidade cultural. 2002. Disponível em: 〈http://unesdoc.unesco.org/images/0012/001271/127160por.pdf〉. Acesso em: 25 jan. 2010.

FÓRUM NACIONAL PERMANENTE DO ENSINO RELIGIOSO - FONAPER. Parâmetros Curriculares Nacionais do Ensino Religioso. São Paulo: Ave Maria, 1997.

HAMER, D. 0 gene de Deus. São Paulo: Mercuryo, 2005.

HAY, D. P.; SOCHA, M. The science looks at spirituality as natural phenomenon: bringing biological and psychological perspectives together. Zygon, v. 40, n. 3, p. 589-612, 2005. 
JUNQUEIRA, S. R. A. et al. Ensino religioso: aspectos legal e curricular. São Paulo: Paulinas, 2007.

KIVITZ, R. Religião e outra espiritualidade. Disponível em: <www.outraespiritualidade.blogspot.com>. Acesso em: 22 nov. 2008.

KÜNG, H. Projeto de ética mundial: uma moral ecumênica em vista da sobrevivência humana. 4. ed. São Paulo: Paulinas, 2003.

MARINO Jr., R. A religião do cérebro: as novas descobertas da neurociência a respeito da fé humana. São Paulo: Gente, 2005.

MEDITAÇÕES do pôr-do-sol. Tatuí: Casa Publicadora Brasileira, 2003.

MONDIN, B. Quem é Deus?: elementos de teologia filosófica. São Paulo: Paulus, 1997.

MORIN, E. Os sete saberes necessários à educação do futuro. 3. ed. São Paulo; Brasília, DF: Cortez; UNESCO, 2001a.

MORIN, E. A religação dos saberes: o desafio do século XXI. Rio de Janeiro: Bertand Brasil, 2001b.

MOSER, A. Para além dos genes: a metáfora do "Livro da Vida". Disponível em: <www.antoniomoser.com>. Acesso em: 20 dez. 2009.

MOSER, A. Ética, valores e educação. 2004. Disponível em: <www.antoniomoser. com>. Acesso em: 10 jan. 2010.

NOUAILHAT, R. Enseigner le fait religieux; um défi pour la läiité. Nathan, 2004.

NOVAK, J. D. Uma teoria da educação. São Paulo: Pioneira, 1981.

OLIVEIRA, L. et al. Ensino Religioso no Ensino Fundamental. São Paulo: Cortez, 2007.

PANIKKAR, R. Ícones do mistério: a experiência de Deus. São Paulo: Paulinas, 2007.

PASSOS, J. D. Ensino religioso: construção de uma proposta. São Paulo: Paulinas, 2007. 
QUEIROZ, J. J. Deus e a espiritualidade sob olhares científicos Pós-Modernos: limites e possibilidades da nova Biologia, da Genética e da Neurociência no campo da(s) Ciência(s) da Religião. In: CONFERÊNCIA NO PRIMEIRO SIMPÓSIO LUSOBRASILEIRO DE FILOSOFIA DA RELIGIÃO E CIÊNCIAS DA RELIGIÃO, 1., 2009, Braga. Anais... Braga: Conferência no Primeiro Simpósio Lusobrasileiro de Filosofia da Religião e Ciências da Religião, 2009.

QUINTÁS, A. L. Inteligência criativa: descoberta pessoal de valores. São Paulo: Paulinas, 2007.

SANCHEZ, W. L. Pluralismo religioso: as religiões do mundo atual. São Paulo: Paulinas, 2005.

SMARJASSI, C. M. Uma análise Ausubeliana de aprendizagem significativa: a organização e transmissão de conteúdos em cursos de formação de professor. 1996. 139 f. Dissertação (Mestrado em Educação) - Programa de Pós-Graduação da Pontifícia Universidade Católica de São Paulo, São Paulo, 1996.

SOARES, A. M. L. (Coord.). Temas do ensino religioso. Apresentação. In: PASSOS, J. D. Ensino religioso: construção de uma proposta. São Paulo: Paulinas, 2007. p. 5-9.

TILLICH, P. Teologia sistemática. 5. ed. Tradução de Getúlio Bertelli e Geraldo Korndörfer. São Leopoldo: Sinodal, 2005.

TRACY, D. Metáforas e religião: o caso dos textos cristãos. In: SACKS, S. (Org.). Da metáfora. Tradução de Stella Tagnin. São Paulo: EDUC-Pontes, 1992. p. 95-99.

YUS, R. Educação integral: uma educação holística para o século XXI. Porto Alegre: Artmed, 2002.

Recebido: $15 / 03 / 2010$

Received: 03/15/2010

Aprovado: 18/05/2010

Approved: 05/18/2010 


\section{Anexo}

\section{Religião e outra espiritualidade ${ }^{6}$}

Qual a diferença entre espiritualidade e religião?

Espiritualidade é a experiência humana do sagrado, transcendente, divino. Religião é a maneira como o ser humano organiza e vivencia esta experiência. Espiritualidade é uma experiência humana universal. Religião é uma experiência humana condicionada a dogmas, ritos, códigos morais e grupos de pessoas que acreditam nas mesmas coisas e celebram sua espiritualidade da mesma maneira. As religiões mais conhecidas no mundo são Judaísmo, Cristianismo, Hinduísmo e Budismo. A espiritualidade é o que os seres têm em comum. Por exemplo, tanto Dalai Lama quanto o Papa Bento XVI têm uma espiritualidade, mas têm religiões diferentes. Um é budista e o outro é cristão. Em termos simples, assim como o ser humano tem corporeidade (relação com o corpo) e racionalidade (relação com a mente), também tem espiritualidade (relação com as realidades espirituais). Religião é a maneira como cada ser humano desenvolve e pratica sua espiritualidade.

Por que outra espiritualidade?

Dentro de cada religião existe um número variado de maneiras de vivenciar a espiritualidade. Por exemplo, no Cristianismo a espiritualidade pode ser vivida de uma forma Católica Romana e outra Protestante, e mesmo dentro do Protestantismo, existem ramificações como o protestantismo histórico, o pentecostalismo e o neo-pentecostalismo. No Brasil,

6 KIVITZ, 2008. 
os protestantes ficaram conhecidos como "evangélicos". Isto é, "evangélico" é um ramo do protestantismo, que por sua vez é um ramo do Cristianismo, que por sua vez é uma das cinco grandes religiões. Ser "evangélico", portanto, é uma forma de viver a espiritualidade cristã, e nesse caso podemos dizer que existe uma outra maneira de viver a espiritualidade cristã, diferente da maneira como os evangélicos a vivem.

\section{0 renascer da águia ${ }^{7}$}

“... de sorte que a tua mocidade se renova como a da águia" (Sl. 103,5)

Mas os que esperam no Senhor renovarão as suas forças, subirão com asas como águia, correrão e não se cansarão; caminharão e não se fatigarão" (Is. 40,31)

A sobrevivência é a primeira lei da natureza. Normalmente, uma pessoa daria tudo ou faria qualquer coisa para preservar a própria vida.

A águia é a ave que possui maior longevidade da espécie, chegando a viver setenta anos. Mas, para chegar a essa idade, aos quarenta anos, ela tem que tomar uma séria e difícil decisão. Nessa idade, ela está com as unhas compridas e flexíveis e não consegue mais agarrar as suas presas, das quais se alimenta. $\mathrm{O}$ bico alongado e pontiagudo se curva, dificultando a caça. Apontando contra o peito estão as asas, envelhecidas e pesadas em função da grossura das penas e voar se torna difícil.

Então, a águia só tem duas alternativas: morrer ou enfrentar um dolorido processo de renovação que irá durar aproximadamente 150 dias. Esse processo consiste em voar para o alto de uma montanha e recolherse em um ninho próximo a um paredão, onde ela não necessite voar. Após encontrar esse lugar, a águia começa a bater com o bico contra a pedra até conseguir arrancá-lo. Após arrancá-lo, espera nascer um novo bico, com o qual vai depois arrancar suas unhas. Quando as novas unhas começam

7 MEDITAÇÕES, 2003, p. 33. 
a nascer, ela passa a arrancar as velhas penas. Só então, após cinco meses, sai para o famoso vôo de renovação, para viver por mais 30 anos.

Em nossa vida, quando as condições não estão como gostaríamos que estivessem, muitas vezes temos de nos resguardar por algum tempo e começar um processo de renovação. Para que continuemos a voar um vôo de vitória, devemos nos desprender de lembranças, costumes e outras tradições que nos causaram dor. Somente livres do peso do passado, poderemos aproveitar o resultado valioso que uma renovação sempre traz.

Procuremos tirar lições dos infortúnios e permitamos que Deus faça as transformações necessárias. Renovemos, a cada dia, nossos objetivos, sonhos, nossas esperanças, nossa fé.

Sigamos o exemplo da águia. Tomemos hoje, a decisão de mudar a nossa vida. Definamos quais são nossos objetivos, sonhos e necessidades. Usemos as ferramentas que temos à mão. Aproveitemos as oportunidades.

A cada dia, consultemos com muito carinho o "Assim diz o Senhor". É esse crescer constante que nos traz a verdadeira paz. É essa renovação constante que agrada ao nosso amável Deus. 